\title{
AL-AZHAR
}

The Official Publication of The

Assiut Dental Journal

Faculty of Dental medicine.

Al-Azhar Assiut Uniuersity.

Equpt

AADJ, Vol. 2, No. 2, October (2019) - PP. 109:115

ISSn 2682-2822

\section{Locator versus Ball and Socket Attachment Systems for Single Implant Retained Mandibular Overdenture (Retention -Oral health related quality of life)}

\author{
Fayadd MI' ${ }^{* 1,2}$, Osman MA ${ }^{1}$, Haddad DF ${ }^{1}$, Quassemc MA ${ }^{1}$
}

Codex : 13/1910

Aadj@azhar.edu.eg

\section{KEYWORDS}

Implant, overdenture, retention, Patient oral health and quality of life, attachments, ball and socket, locators.

1. Department of Removable Prosthodontics, Faculty of Dental Medicine, Al-Azhar University, (Cairo, boys), Egypt.

2. Department of Substitutive Dental Science, College of Dentistry, Taibah University, Sauid Arbia.

* Corresponding Author e-mail: dr.mifayad@azhar.edu.eg

\begin{abstract}
Aim: It was to compare Locator versus ball and socket attachment systems for single implant retained mandibular overdenture in relation to retention and oral health related quality of life. Subjects and Methods: Twenty completely edentulous patients were randomly selected from the Outpatient Clinic. Patients were divided into two groups, group (I) received single implant retained overdenture with ball and socket attachment while group (II) received single implant retained overdenture with locator attachment. Retention was measured three months interval after overdenture insertion for one year using force gauge device. Oral healthrelated quality of life was evaluated using OHIP-EDENT questionnaire after one year of overdenture insertion. Results: Group (II) recorded higher retention values than group (I) and the difference was statistically significant. Group I recorded higher Oral healthrelated quality of life mean values than group II and the difference was statistically non- significant. Conclusion: Locator attachment significantly increases retention of implant retained overdenture than ball and socket attachment. There is no significant difference in Patient oral health and quality of life between locator and ball attachments.
\end{abstract}

\section{INTRODUCTION}

The concept of implant retained overdenture was applied successfully. It ensures comfort, stability and painless option for edentulous patients and also enhances the quality of life and oral health. But the major problem with implant retained over dentures still the high cost of the implants ${ }^{[1]}$.

Economic reasons especially among the emerging elderly population in developing countries make this treatment strategy financially challenging. In order to reduce the cost and time of treatment, the concept of single implant-retained over denture provides another option for elderly populations ${ }^{[1-4]}$.

The selection of attachment system depend on, amount of retention needed, available inter arch space, manual dexterities of the patient, skills of the dentist and finally the cost ${ }^{[5]}$. 
Several studies concluded that for un-splinted implants, the most common attachment used is the ball and socket attachment system. it is a practical, effective, and relatively low-cost prosthetic concept $t^{[6-8]}$.

The locator attachment system is an attachment system with self-aligning feature and has dual retention (inner and outer). Locator attachments come in different colors (white, pink, and blue), and each has different retentive value. Additional features are the extended range attachments, which can be used to correct implant angulation up to 20 they are offered in green, which has standard retention, and red, which has extra-light retention. The reduced height of this attachment is advantageous for cases with limited interocclusal space ${ }^{[9,10]}$.

Therefore, this study was done to compare Locator versus ball and socket attachment systems for single implant retained mandibular overdenture in relation to retention and oral health related quality of life.

\section{PATIENTS AND METHODS}

Twenty completely edentulous patients with average age of 45-55 years free from any systemic diseases that might affect implant placement were randomly selected from the Outpatient Clinic, Department of Removable Prosthodontics, Faculty of Dental Medicine, Al-Azhar University (Boys, Cairo). Informed consent was obtained from all patients after an explanation of the methodology prior to enrolment in the study.

\section{Prosthodontics phase of the treatment:}

An acrylic complete denture was constructed for each patient following the conventional steps for complete denture construction with bilateral balanced occlusion concept. After the denture was finished and polished, it inserted in the patient's mouth and verification of esthetics, retention, stability, occlusion, high spots and any sharp or overexten- sion that may cause pain were done. Post insertion instructions were done; patients were instructed to wear the dentures till adaptation was acquired.

\section{Implant placement:}

Following single stage surgical protocol, Single dental implant fixture (Dentis, Dalseo-gu, Daegu, Korea) with Implant length $10 \mathrm{~mm}$, Implant diameter $3.7 \mathrm{~mm}$ were placed at midline of mandibular alveolar ridge. Patients were randomly allocated into two groups according to attachment used. Group I: Patients received ball and socket attachment (Fig 1). Group II: Patients received locator attachment (Fig 2). Housings were created in the fitting surface of the denture to receive the female part or the attachments using auto- polymerizing acrylic resin.

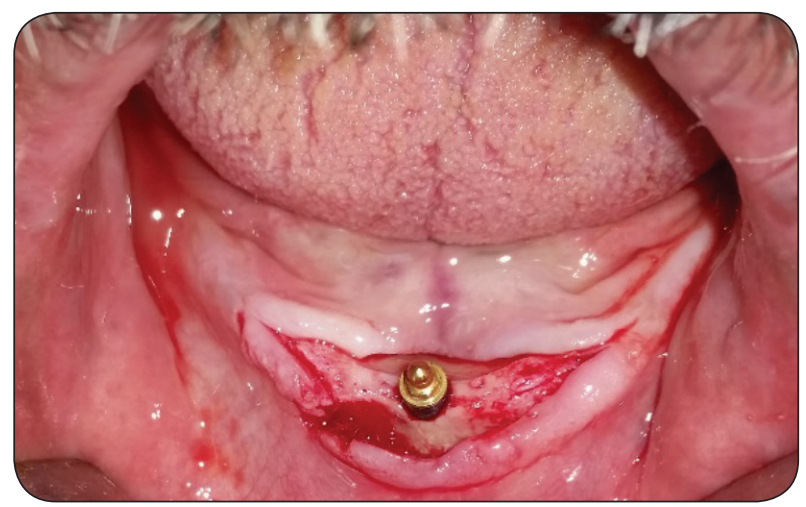

Fig. (1) Ball and socket

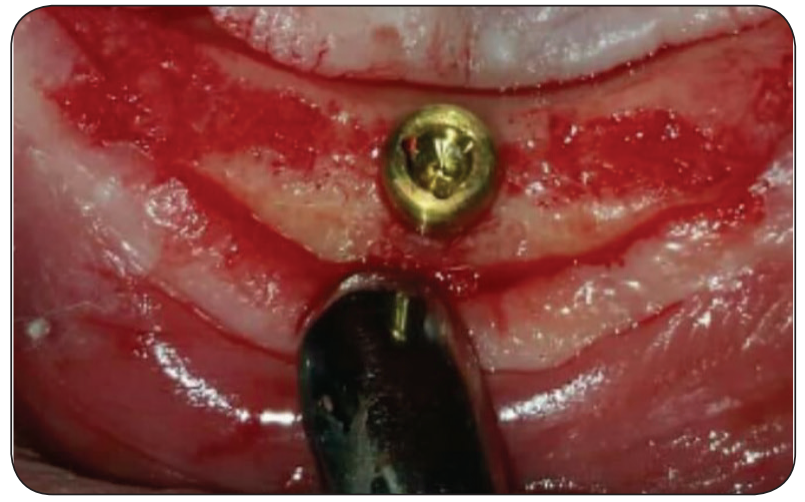

Fig. (2) Locator attachment 


\section{Observations}

In this study each patient in group I received mandibular overdenture retained by Ball and socket attachment while each patient in group II received mandibular overdenture retained by locator attachment system.

A: Retention of the overdenture to the implant via the different attachment systems(group I and group II ) was measured at three months interval for one year after overdenture insertion as the following:

The geometric center of the lower denture was relatively identified, and a rigid wire $(0.9 \mathrm{~mm}$ stainless wire) were used to make retentive hook within the geometric center to be attached to the force gauge to start evaluation and measurement of retention. Wire with a hook was attached to the denture base with self-curing acrylic resin to allow force gauge device (FG-5000, Extech Instruments. USA) to exert vertical dislodging force on the denture. Dentures were inserted intra-orally and the force gauge adjusted to measure peak force needed to dislodge the overdenture. The tip of the force gauge was connected to the wire at the midpoint and the force gauge was pulled in an upward direction until denture retention was lost and the prosthesis was felt loose, then the reading was recorded 3 times and the mean value was calculated.

B: Oral health-related quality of life (OHRQOL): The oral health-related quality of life was evaluated using the Arabic version of the oral health impact profile for edentulous patients [OHIP-EDENT] ${ }^{[11]}$. Oral examination was carried out by a single examiner and denture wearing status was recorded after completion of questionnaire, after 12 months of overdenture insertion.

Table (1) Questionnaire of oral health impact profile for edentulous patients

\begin{tabular}{|c|c|c|c|c|c|c|}
\hline & & 0: Never & $\begin{array}{l}\text { 1: Hardly } \\
\text { ever }\end{array}$ & $\begin{array}{l}\text { 2: ccasi } \\
\text { onally }\end{array}$ & $\begin{array}{l}\text { 3: Fairly } \\
\text { Often }\end{array}$ & $\begin{array}{l}\text { 4: Very } \\
\text { often }\end{array}$ \\
\hline $\begin{array}{l}\mathrm{FL}=\text { Functional } \\
\text { limitation }\end{array}$ & $\begin{array}{l}1 \text { Difficulty chewing any foods? } \\
2 \text { Food catching in your dentures? } \\
3 \text { Dentures not fitting properly? }\end{array}$ & & & & & \\
\hline P1=Physical pain & $\begin{array}{l}4 \text { Painful aching in your mouth? } \\
5 \text { Uncomfortable to eat any foods? } \\
6 \text { Sore spots in your mouth? } \\
7 \text { Uncomfortable dentures? }\end{array}$ & & & & & \\
\hline $\begin{array}{l}\text { P2=Psychological } \\
\text { discomfort }\end{array}$ & $\begin{array}{l}8 \text { Worried by dental problems? } \\
9 \text { Self-conscious? }\end{array}$ & & & & & \\
\hline $\begin{array}{l}\text { D1=Physical dis- } \\
\text { ability }\end{array}$ & $\begin{array}{l}\text { 10. Avoid eating some foods? } \\
11 \text { Unable to eat? } \\
\text { 12. Interrupt meals? }\end{array}$ & & & & & \\
\hline $\begin{array}{l}\text { D2=Psychological } \\
\text { disability }\end{array}$ & $\begin{array}{l}13 \text { Upset? } \\
\text { 14. A bit embarrassed? }\end{array}$ & & & & & \\
\hline $\begin{array}{l}\text { D3=Social dis- } \\
\text { ability }\end{array}$ & $\begin{array}{l}\text { 15. Avoided going out? } \\
\text { 16. Less tolerant } 01 \text { partner or family? } \\
\text { 17. Irritable with other people? }\end{array}$ & & & & & \\
\hline $\mathrm{H}=$ Handicap & $\begin{array}{l}\text { 18. Unable to enjoy another people's company } \\
\text { as much? } \\
19 \text {. Fell that life in general was less satisfying }\end{array}$ & & & & & \\
\hline
\end{tabular}




\section{RESULTS}

The data were collected, tabulated and statistically analyzed using $\operatorname{SPSS}^{\odot}$ for windows. The data distribution of normality was done by using Kolmogorov-Smirnov test. The test showed normal distribution of data and student t-test was used for statistical analysis. The significance level was set at $\mathrm{P} \leq 0.05$. Statistical analysis was performed with SPSS $^{\odot}$ Statistics Version 20 for Windows.

\section{Measuring the retention force of mandibular over denture:}

Three months after loading, it was found that group1 (ball and socket) recorded a lower mean value $(\mathbf{8 . 1 2} \mathrm{N})$ than group2 mean value $(\mathbf{1 1 . 3 6} \mathrm{N})$, the difference between the two groups were statistically significant as indicated by $\mathrm{t}$-test as $(\mathrm{p}<0.05)$.

Six months after loading, it was found that, group I (ball and socket) record a lower mean value (46.57 \pm 5.44$)$ than group II (locator) mean value $(37.78 \pm 11.08)$, the difference between the two groups was statistically significant as indicated by $\mathrm{t}$-test as $(\mathrm{p}<0.05)$.

Nine months after loading, it was found that group I recorded a lower mean value $(7.75 \mathrm{~N})$ than group II $(\mathbf{1 0 . 6 9 N})$ the difference between the two groups was statistically significant as indicated by t-test as $(\mathrm{p}<0.05)$.

12 months after loading, it was found that group I (ball and socket) recorded a lower mean value( $\mathbf{7 . 3 2 N}$ ) group II (locator) $(\mathbf{1 0 . 1 4 N})$, the difference between the two groups was statistically significant as indicated by t-test as $(\mathrm{p}<0.05)$.

\section{Oral healthrelated quality of life (OHRQoL):}

It was found that group I recorded a higher mean value regarding total mean value of OHRQoL (12.397) than group II (12.212). The difference between the two groups was statistically non-significant as indicated by $\mathrm{t}$-test as $(\mathrm{p}>0.05)$. It was found that group1 recorded a lower mean value regarding function (1.832) than group II (2.180). The difference between the two groups was statistically non-significant as indicated by t-test as $(\mathrm{p}>0.05)$. It was found that group I recorded a higher mean value regarding physical Pain (1.750) than group II (1.610), the difference between the two groups was statistically non-significant as indicated by $\mathrm{t}$ test as $(\mathrm{p}>0.05)$. It was found that group1 recorded a higher mean value regarding psycho-discomfort (1.976) than group II (1.720), the difference between the two groups was statistically non-significant as indicated by $t$-test as ( $p>0.05)$. It was found that group I recorded a higher mean value regarding physic-disability (1.510) than group II (1.450), the difference between the two groups was statistically non-significant as indicated by $t$-test as $(\mathrm{p}>0.05)$. It was found that group I recorded a lower mean value regarding psycho Disability (1.710) than group II (2.205), the difference between the two groups was statistically non-significant as indicated by t-test as $(p>0.05)$. It was found that group I recorded a lower mean value regarding social disability (1.220) than group II (locator) (1.375), the difference between the two groups was statistically non-significant as indicated by $\mathrm{t}$-test as $(\mathrm{p}>0.05)$. It was found that group I recorded a higher mean value regarding handicap (2.110) than group II (2.100), the difference between the two groups was statistically nonsignificant as indicated by $\mathrm{t}$-test as $(\mathrm{p}>0.05)$.

\section{DISCUSSION}

Overdenture retained by single implant placed in the midline of the mandible has shown to be a successful prosthetic treatment modality because of minimized risks in surgical procedure, avoid injury to inferior alveolar nerve and it is an area of good bone quality, thickness and height ${ }^{[12]}$.

Locator attachments (group I) recorded higher retention values than ball and socket (group II). These results come in agreement with an in vitro 
study compared the retentive properties of ball and locator attachments for implant overdenture; it concluded that both attachment systems showed decreased retentive forces after 5,000 insertionseparation cycles. However, after 5,000 insertion separation cycles, locator attachments showed better retentive properties than ball attachments ${ }^{[13]}$.

These results also come in agreement with studies that compared between different types of attachments in regard to retention; it concluded that locator attachment has the highest value of retention force when compared with other types of implant over denture attachments ${ }^{[14,15]}$.

Ball and socket attachment (group II) recorded a higher total mean value of OHRQoL than locator attachment (group I), but the difference was statistically nonsignificant. These results consistent with study compared three different attachment systems for mandibular implant overdentures after one year. 23 patients received a self-aligning attachment system (Locator) and 33 patients a ball attachment and 25 TG-O-Ring. After 12 months of delivery of the overdenture's oral health-related quality of life was assessed using (Oral Health Impact Profile [OHIP-G 49]) showed no significant difference among the three experimental groups ${ }^{[16]}$.

\section{CONCLUSION}

Within the limitations of the present study, the following conclusions can be drawn:

1. Locator attachment significantly increase retention of implant retained overdenture than ball and socket attachment.

2. There is no significant difference in Patient oral health and quality of life between locator and ball attachments.

3. Single implant overdenture is a successful economical treatment modality for completely edentulous patients suffering from impaired mandibular denture retention.

\section{REFERENCES}

1. Barai, G.D., et al., FEM analysis of single implant retained mandibular overdenture with four different attachment types: A review. International J. of Healthcare and Biomedical Research, 2016. 4(2): p. 29-34.

2. Walton JN, Glick N, and M. MI., A Randomized Clinical Trial Comparing Patient Satisfaction and Prosthetic Outcomes with Mandibular Over Dentures Retained by One or Two Implants. Int J Prosthodont, 2009;22:331-9. 22: p. 331-339.

3. Chenga $\mathrm{T}$, et al., Use of A Single Implant to Retain Mandibular Overdenture: A preliminary clinical trial of 13 cases. J.Dental science, 2012. 7: p. 261-266.

4. Shajahan J U, et al., Single Implant Retained Mandibular Overdenture A Literature Review. Int $\mathbf{J}$ of Oral Health Dent. Int J of Oral Health Dent, 2015. 7: p. 261-266.

5. Ahmed Y A and A.F. K. Attachments Used with Implant Supported Over Denture. Int Dent \& Med J of Advan Res, 2016. 2: p. 1-5.

6. Winkler, S., et al., An overview of the O-ring implant overdenture attachment: clinical reports. J Oral Implantol, 2002. 28(2): p. 82-6.

7. Krennmair G, et al., Implant-supported mandibular overdentures retained with ball or telescopic crown attachments: A 3-year prospective study. Int J Prosthodont 2006. 19: p. 164-70

8. Gotfredsen, K., et al., Marginal tissue response adjacent to Astra Dental Implants supporting overdentures in the mandible. Clin Oral Implants Res, 1993. 4(2): p. 83-9.

9. Evtimovska E, et al., Th e change in retentive values of locator attachments and hader clips over time. J Prosthodont 2009. 18: p. 479-83.

10. Pasciuta M, Grossmann Y, and F. IM.,A prosthetic solution to restoring the edentulous mandible with limited interarch space using an implant-tissue-supported overdenture: A clinical report. J Prosthet Dent 2005. 93: p. 116-20.

11. Mostafa Fayad and H.M. Sakr, bite force and oral health impact profile in completely edentulous patients rehabilitation with two different types of denture bases. tanta dsental journal, 2017 . 14 :p .173 -80.

12. Mahoorkar, S., S. Bhat, and R. Kant, Single implant supported mandibular overdenture: A literature review. The Journal of the Indian Prosthodontic Society, 2016. 16(1): p. $75-82$. 
13. Turk, P.E., et al., In vitro comparison of the retentive properties of ball and locator attachments for implant overdentures. Int J Oral Maxillofac Implants, 2014. 29(5): p. 1106-13.

14. Miler, A., et al., Locator(R) attachment system for implant overdentures: a systematic review. Stomatologija, 2017. 19(4): p. 124-29.
15. EE., D., Stud attachments for the mandibular implantretained overdentures: Prosthetic complications. A literature review. Saudi Dent J 2013. 25: p. 53-60.

16. Kleis WK, et al., A comparison Of Three Different Attachment Systems For Mandibular Two-Implant Over dentures: One-Year Report. Clin Implant Dent Relt Res., 2010. 12: p. 209-18. 


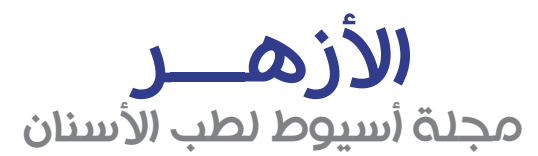

النشر الرسمي لكلية طب الأسنان

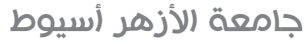

\title{
نظام اللوكاتور مقابل أنظمة الكرة ومقبس المرفق لتثبيت

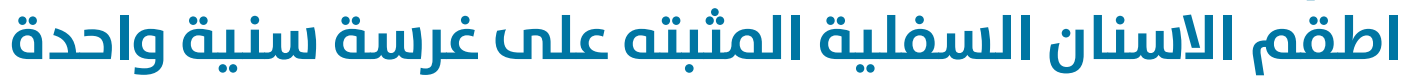

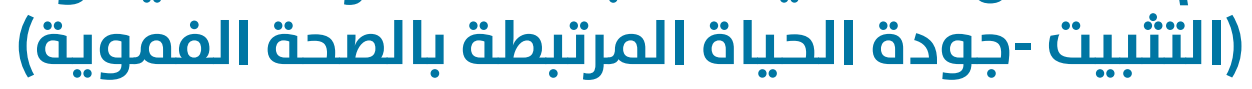

\author{
محمد عباس عثمان، دياب فؤاد الحداد , محمد عبد الله قاسه، مصطفى ابراهيم فياض

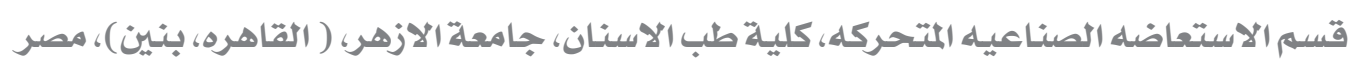 \\ البريد الالكترونى: DR.MIFAYAD@AZHAR.EDU.EG
}

الملخص :

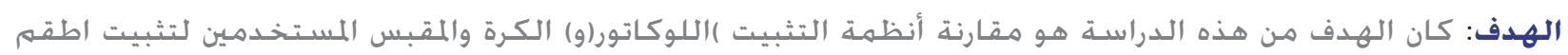

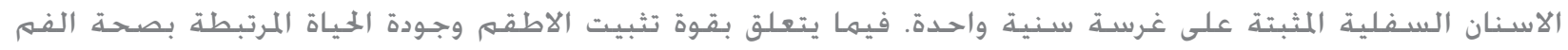
والأسـنان.

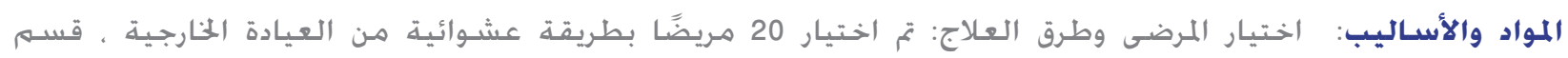

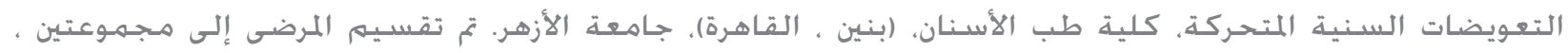

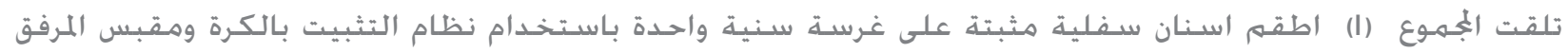

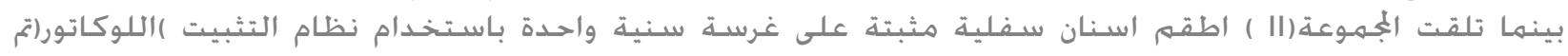

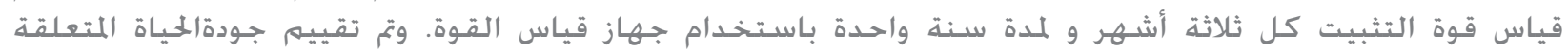

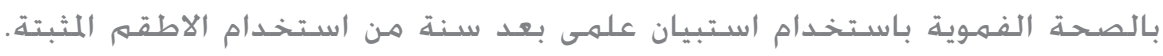

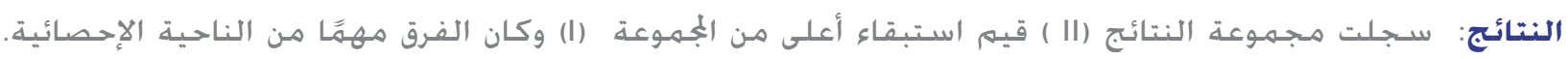

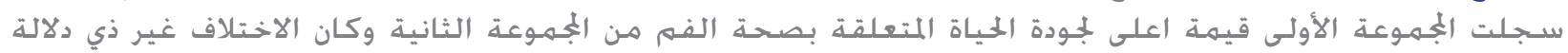
إحصائية. الجمات

الخلاصه: استنتج من الدراسـة ان استخــام نظام التثبيت (اللوكاتور) يزيد بشكل كبير من تثبيت اطقم الاسـنان

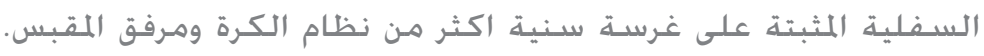

الكلمات المفتاحيه:غرسه سـنيه، اطقم الاسـنان السفلية المثبتة على غرسـة سـية، تثبيت، جودة الحياة المرتبطة بالصحة الفموية,اتصال، نظام الكره ومرفق المقبس، اللوكاتور. 